\title{
Realities of Microenterprises' ICT Use for Business Activities and for Acquiring Online Government Support: A Study in Western Cape Province, South Africa
}

\section{Muhammad Ameer Osman}

MCom Graduate, Information Systems, Faculty of Commerce, University of Cape Town https://orcid.org/0000-0002-0381-6991

\section{Donald Flywell Malanga}

PhD Candidate, Information Systems, Faculty of Commerce, University of Cape Town https://orcid.org/0000-0001-9681-6503

\section{Wallace Chigona}

Professor of Information Systems, Faculty of Commerce, University of Cape Town https://orcid.org/0000-0002-1059-811X

\begin{abstract}
This article provides findings from a study, in South Africa's Western Cape Province, of microenterprises' experiences and perceptions of use of information and communication technologies (ICTs) for general business activities and for acquiring online government business support information. Using the capability approach (CA) theoretical framework, the study analysed data from interviews with microenterprise owners and digital government experts. The study found that the microenterprises were adept in their use of ICTs in their businesses, but that they encountered problems in using online government business support information services. These problems were found to be the result of deficiencies in the online services' content, structure, design, navigation, mobile-friendliness, language usage and bureaucratic requirements.
\end{abstract}

\section{Keywords}

microenterprises, digital government, e-government, government business support information, government websites, information and communication technologies (ICTs), capability approach (CA), Western Cape, South Africa

\section{Acknowledgements}

This article draws on the lead author Osman's research conducted during completion of the degree of Master of Commerce in Information Systems at the University of Cape Town, and on a conference paper presented at Digital Skills 2019: Digital Innovation and Transformation Conference, 29 August 2019, Boksburg, South Africa.

DOI: https://doi.org/10.23962/10539/28659 


\section{Recommended citation}

Osman, M. A., Malanga, D. F., \& Chigona, W. (2019). Realities of microenterprises' ICT use for business activities and for acquiring online government support: A study in Western Cape Province, South Africa. The African Journal of Information and Communication (AJIC), 24, 1-23. https://doi.org/10.23962/10539/28659

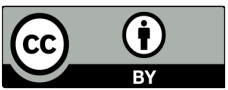

This article is licensed under a Creative Commons Attribution 4.0 International (CC BY 4.0) licence: https://creativecommons.org/licenses/by/4.0

\section{Introduction}

Microenterprises play a significant role in the socio-economic development of numerous developing countries, including South Africa (Makoza \& Chigona, 2014). They provide income generation, sources of employment, and improved social conditions for disadvantaged or "underserved" communities (Chacko \& Harris, 2006; Duncombe \& Heeks, 2005). In this study, microenterprises are defined as businesses with fewer than 10 employees that support the livelihood of households in developing nations for economic development (Makoza \& Chigona, 2012). The majority of microenterprises fail to survive or to grow due to myriad challenges, including lack of access to information, difficulty securing capital, limited business skills, difficulty identifying markets, and difficulty understanding the regulatory requirements for a business (DTI, n.d.). As a result, most microenterprises do not survive beyond their first two years (Makoza \& Chigona, 2014).

Prior studies have shown that the use of information and communication technologies (ICTs), such as mobile phones, social media platforms and government websites, can offer solutions to some of the challenges facing microenterprises. ICTs can provide improved access to information, reduced administrative costs, improved productivity and profitability, operational efficacies, and improved market share (Kamal \& Qureshi, 2009). The use of digital government (also often referred to as "electronic government" or "e-government") websites providing government-to-business (G2B) services can reduce the time and costs that businesses expend in accessing the information needed for setting up a new business (i.e., through reduced bureaucratic barriers), can improve conformity to government rules and regulations for operating a business (e.g., licensing and tax filing), and can facilitate microenterprises' provision of paid services to government through e-procurement, e-business and e-commerce portals (Makoza, 2011).

Studies suggest that, in developing countries, microenterprises struggle to access online digital government support services because, inter alia, they lack sufficient access to ICTs (Kamal \& Qureshi, 2009; Makoza, 2011). This can be exacerbated by a lack of ICT skills and/or low literacy levels of microenterprise entrepreneurs, 
insufficient resources to procure and maintain ICTs, and the poor quality of some government websites, including poorly organised information (PMG, 2012; Venter \& Lotriet, 2005). Other developing-country research has probed factors influencing the adoption and implementation of digital government (Bwalya, Du Plessis \& Rensleigh,2013; Bwalya \& Healy, 2010; Grönlund,2011). However, microenterprises' use of online government support information has not been widely explored.

Likewise, in South Africa, microenterprises' use of ICTs for business activities and for online government business support information has received marginal attention. Studies on the impact of ICT use in South Africa have largely focused on small and medium enterprises (SMEs), with a focus on areas such as productivity and formalisation (Makoza, 2011). The G2B category has also not received attention in the South African literature on digital government. The predominant focus has been on citizens, i.e., government-to-citizen (G2C) modalities (Zaidi \& Qteishat, 2012). Therefore, the main objectives of the study described in this article were to explore microenterprises' experiences and perceptions of:

- using ICTs for general business activities; and

- using online government business support information.

The study consisted of interviews with 17 Western Cape microenterprise owners and interviews with two digital government experts. We analysed the data in terms of the capability approach (CA) theoretical framework as developed by Sen and Nussbaum (Nussbaum, 2009; Robeyns, 2003; Sen, 1993).

The hope is that generating greater understanding of how microenterprises experience and perceive ICTs and online government support information services can help government departments to provide tailored digital government services that will benefit microenterprises in South Africa. Eventually, this could have a positive impact on the growth of the country's microenterprise sector, and of the sustainability of individual enterprises. The study was underpinned by the capability approach (CA) theoretical framework (Nussbaum, 2009; Sen, 1993), as recently operationalised in an African context by Nyemba-Mudenda (2014).

\section{Study context}

South Africa's Western Cape Province is home to more than 6.2 million people (Stats SA, n.d.). About half of the province's inhabitants reside in the metropolitan area of Cape Town, which is the provincial capital (City of Cape Town, n.d.). The predominant language spoken in the province is Afrikaans, with English and isiXhosa being the other two leading languages (Western Cape Government, n.d.).

Research in the Delft South and Thabong townships of the Western Cape found that $15 \%$ of all identified microenterprises were operated by individuals who are under the age of 30 years (Charman, 2016). According to the national Department 
of Small Business Development (2019), South African microenterprises can be found engaged in, inter alia, agriculture, mining, manufacturing, construction, retail, automotive repair, catering, accommodation, transport, storage, communications, business services and community services. The Western Cape Government offers support information and services to encourage the development of microenterprises (Makoza, 2011). These services seek to, inter alia, improve the formation of small businesses in underprivileged communities, to build entrepreneurial skills, to decrease unemployment, and to encourage the evolution of microenterprises into SMEs (Makoza, 2011).

In the relevant developing-world research, it has been found that, despite myriad forms of online government business support information services, the use of such business support information has not been optimal, especially by microenterprises (Shambour, 2012). The low use of online government support information services has, in some cases, been attributed to microenterprises not being sufficiently aware of the support being offered and implemented by government departments and development agencies (Mitrovic \& Bytheway, 2009). Another challenge that has been identified is that government support information for small business is not available and/or accessible in rural areas (Makoza, 2011). Evidence has also been found of skepticism among potential information recipients because of the apparent absence of cohesion among the government stakeholders involved in providing support information for small business (Mitrovic \& Bytheway, 2009). Low literacy levels (e.g., personal computer (PC) literacy) have also been found to play a role in limiting microenterprises' use of the support information (Mawela, Ochara \& Twinomurinzi, 2016).

Another element that could limit the use of online government support information by developing-world microenterprises is their informality. Most developing-world microenterprises do not maintain business records and are typically unregistered (Esselaar,Stork,Ndawalana \&Deen-Swarray,2007).Meanwhile, government support will often be contingent on the microenterprises being registered. Rogerson (2008) explains that for microenterprises operating in the informal sector, formalisation in certain instances can limit the business activities that these enterprises can engage in.

Another possible reason for low microenterprise use of online government support information is that the information tends to be siloed and segmented across various levels of government (e.g., in the South African context, the national, provincial and local levels) and across various government departments (Western Cape Government, n.d.).

The Western Cape Province has, in South African terms, a high internet connectivity rate. A 2018 estimate stated that $95.6 \%$ of individuals in the province accessed the internet using a mobile phone, compared to the national average of $70.8 \%$ (RIA \& 
UCT, 2018). The Western Cape Government also offers ICT access initiatives, such as telecentres, which have been established to provide people in underserved areas with access to ICTs and ICT-related services (Kaisara \& Pather, 2011).

\section{Literature review}

\section{Microenterprises in developing countries}

Microenterprises provide, inter alia, sources of income, opportunities for employment, opportunities for skills development, and opportunities for self-empowerment (Makoza, 2011). In South Africa, micro, small and medium-sized enterprises (MSMEs) employ an estimated 50-60\% of the country's workforce and contribute around 34\% of gross domestic product (GDP) (IFC \& World Bank, 2018). In South Africa and other developing countries, microenterprises are usually characterised as being survivalists, because they generate only small revenues, due to the small scale of their business operations (Abor \& Quartey, 2010). Furthermore, as stated above, developing-world microenterprises usually do not maintain business records and are often unregistered (Esselaar et al., 2007), as they mostly operate in the informal sector.

\section{Microenterprises and ICTs}

Duncombe and Heeks (2005) describe ICTs as technologies for capturing, processing, storing and disseminating information. Microenterprises typically use ICTs such as PCs, laptops, mobile phones and printers (Duncombe \& Heeks, 2005). Microenterprises can benefit from using ICTs in the form of improved access to information, reduced administrative costs, improved productivity and profitability, operational efficacies, and improved market share (Kamal \& Qureshi, 2009). For example, by using social networking and a website, updated via a mobile smartphone, microenterprises can reach large numbers of customers at a very low cost, effectively growing and harnessing their social capital (Good \& Qureshi, 2009). Previous research has found that the majority of Cape Town's microenterprises use mobile telephony for the key informational elements of their engagements in trade and commerce (Noruwana, Chigona \& Malanga, 2018).

\section{Microenterprises and online government support information services}

Digital government is the use of ICTs to improve access to, and delivery of, government information services to citizens $(\mathrm{G} 2 \mathrm{C})$, businesses $(\mathrm{G} 2 \mathrm{~B})$ and other government agencies (G2G) (Agangiba \& Kabanda, 2016). Examples of digital government information services include information on business licensing, tax filing, grant submissions, and tendering for government contracts (Good \& Qureshi, 2009; Mutula, 2013).

Microenterprises can access business support information services through government websites (Agangiba \& Kabanda, 2016), which can potentially provide quick and flexible access to necessary information and service delivery options 
(Noruwana et al., 2018; Malik, Shuqin, Mastoi, Gul \& Gul, 2016). However, for digital government websites to be fully accessible and useful, their web-based applications should be easy to interact with, irrespective of the device being used (e.g., mobile device, laptop, PC) (Rubaii-Barrett \&Wise, 2008).

\section{Theoretical framework: The capability approach (CA)}

This study adopted the capability approach (CA) framework developed by Sen and Nussbaum (Nussbaum, 2009; Robeyns, 2003; Sen, 1993), and as recently operationalised in an African context by Nyemba-Mudenda (2014). CA emphasises not amounts or levels of income, but rather capabilities such as "access to healthcare, education, information, participating in economic life and the autonomy in decision making" (Zheng \& Walsham, 2008, p. 224). CA has achieved recognition as a multi-disciplinary analytical instrument and has been used in numerous ICT for development (ICT4D) studies (see, for example, Alexander \& Phahlamohlaka, 2006; Grunfeld, Hak \& Pin, 2011).

The core concepts in CA are commodity, capabilities/potential functionings, conversion factors, functionings, freedom, agency and well-being. Table 1, from Nyemba-Mudenda (2014, p. 56), summarises the core CA concepts.

Table 1: Capability approach (CA) core concepts

\begin{tabular}{|c|c|c|}
\hline Concept & Description & Examples \\
\hline Commodity & $\begin{array}{l}\text { Resources-their characteristics, access, and use to } \\
\text { generate capabilities for a person }\end{array}$ & $\begin{array}{l}\text { Services, products, } \\
\text { goods }\end{array}$ \\
\hline $\begin{array}{l}\text { Capabilities/ } \\
\text { Potential } \\
\text { functionings }\end{array}$ & $\begin{array}{l}\text { The alternative combinations of actions/activities } \\
\text { that are feasible for a person to achieve-things that } \\
\text { a person is effectively able to do and to live a life they } \\
\text { value }\end{array}$ & To be health $[y]$ \\
\hline $\begin{array}{l}\text { Conversion } \\
\text { factors }\end{array}$ & $\begin{array}{l}\text { Individual capacities or personal characteristics and } \\
\text { social structures that affect the transformation of } \\
\text { capabilities into achieved outcomes }\end{array}$ & $\begin{array}{l}\text { Intellect, } \\
\text { socio-cultural } \\
\text { factors }\end{array}$ \\
\hline Functionings & $\begin{array}{l}\text { What a person chooses to be or to do from their } \\
\text { capability set to live a life they value (achieved out- } \\
\text { comes) }\end{array}$ & Being literate \\
\hline Freedom & $\begin{array}{l}\text { Choice in terms of people's preferences and perceived } \\
\text { value of goods (the freedom to lead different types of } \\
\text { life is reflected in the person's capability set) }\end{array}$ & $\begin{array}{l}\text { Choice, } \\
\text { preferences }\end{array}$ \\
\hline Agency & $\begin{array}{l}\text { A person's ability to pursue and realise goals that he/ } \\
\text { she values and has a reason to value }\end{array}$ & \\
\hline Well-being & $\begin{array}{l}\text { The state of being health, happy or prosperous; } \\
\text { welfare }\end{array}$ & \\
\hline
\end{tabular}

Source: Nyemba-Mudenda (2014, p. 56) 


\section{Commodities}

In CA, commodities are goods and services that are of specific importance to individuals and =they do not have to be income- or money-related (Robeyns, 2006). The use of commodities contributes to social situations and to personal characteristics, which successively feed back to conversion factors and decision-making instruments (Robeyns, 2006). The commodities in this study were:

- ICTs for general business activities; and

- online government business support information.

CA analysis goes beyond commodity access. It seeks to understand individual differences, capabilities and decisions, so as to determine why people use commodities, and how they use and value these commodities (Alampay, 2006).

\section{Capabilities and functionings}

In CA, a functioning is an achievement, while a capability is an ability to achieve. Therefore, there is a relationship between functionings and capabilities (Zheng \& Walsham, 2008). Capabilities can be understood as actions and activities in which an individual would like to participate, and which represent elements that the individual aspires to (Robeyns, 2005).

Certain capabilities need, for their development, financial resources and economic production, whereas other capabilities are more reliant on institutional settings, political arrangements, social or cultural practices, and social structures and norms (Zheng \& Walsham, 2008).

Examples of functionings are being literate, being part of a community, being confident, and working with others (Robeyns, 2006). In the context of this study, microenterprises' access to, and understanding of how to use, ICTs and online government support information services were treated as capabilities. Instances of microenterprises harnessing these capabilities to search for, and acquire, relevant business support information on the internet using digital government websites were treated as functionings.

\section{Conversion factors}

In CA, the relationship between a commodity and functionings is affected by conversion factors, which include environmental factors, social factors and personal characteristics (Robeyns, 2005). Environmental factors entail elements such as geographical position, infrastructure, and resources; social factors include power relations, cultural beliefs and practices, and social norms; and personal characteristics include gender, literacy, and physical condition (Nyemba-Mudenda \& Chigona, 2017). 


\section{Freedom}

In CA, freedom denotes decisions and actions taken by individuals with regard to their personal lives in particular circumstances (Robeyns, 2003). Full freedom is when individuals have the freedoms or valued opportunities to live the type of life they would like to live, to do what they would like to do, and to be the individuals they would like to be (Nyemba-Mudenda, 2014).

\section{Agency and well-being}

In CA, agency is the freedom to plan and follow an individual's own objectives and interests, with the pursuit of well-being, e.g., via a better standard of living, constituting a potential objective or interest (Zheng \& Walsham, 2008).

\section{Justification for use of the CA approach}

Although CA has been criticised for being methodologically vague, it was chosen for this study because it allowed for an exploratory approach and interpretive methods, whereby microenterprise owners could define and select relevant capabilities in their contexts (Nyemba-Mudenda \& Chigona, 2017). Grounded in the CA approach, the study looked at two sets of commodities-(1) ICTs for general business activities; and (2) online government business support information-and at the capabilities, conversion factors, and functionings linked to these commodities, in the experiences and perceptions of the interviewed Western Cape microenterprise owners.

\section{Study methodology}

Data was collected via document analysis and semi-structured interviews. The primary documents analysed were government policies and reports, annual reports, and published statistics necessary to establish the context of the Western Cape microenterprises that were targeted. Semi-structured interviews were conducted with 17 microenterprise owners and two digital government experts (from the City of Cape Town and the Cape Winelands District Municipality).

The target population for the interviews consisted of microenterprises in the Western Cape, South Africa, that were using ICTs. The province's two largest municipalities, Cape Town and the Cape Winelands, were targeted because of their active involvement in the province's digital government and ICT programmes. Table 2 provides information on the 17 microenterprises whose owners were interviewed for the study. 
Table 2: The 17 microenterprise owners interviewed

\begin{tabular}{|c|c|c|c|}
\hline $\begin{array}{l}\text { Respondent } \\
\text { number }\end{array}$ & Nature of microenterprise & $\begin{array}{c}\text { Enterprise's } \\
\text { years since } \\
\text { establish- } \\
\text { ment } \\
\end{array}$ & Respondent gender \\
\hline Respondent 1 & $\begin{array}{l}\text { Metal manufacturing and } \\
\text { welding }\end{array}$ & 3 & Male \\
\hline Respondent 2 & Mobile phone accessories & 13 & Male \\
\hline Respondent 3 & Clothing manufacturing & 6 & Male \\
\hline Respondent 4 & e-Commerce website & 3 & Male \\
\hline Respondent 5 & Business support & 12 & Male \\
\hline Respondent 6 & Clothing retailer & 12 & Female \\
\hline Respondent 7 & Car accessories & 6 & Male \\
\hline Respondent 8 & e-Commerce website & 6 & Male \\
\hline Respondent 9 & Mechanic & 31 & Male \\
\hline Respondent 10 & Locksmith & 4 & Male \\
\hline Respondent 11 & Beautician & 3 & Female \\
\hline Respondent 12 & Bookkeeper & 20 & Male \\
\hline Respondent 13 & Caterer & 25 & Female \\
\hline Respondent 14 & Real estate agent (rentals) & 24 & Female \\
\hline Respondent 15 & Real estate agent (rentals) & 4 & Female \\
\hline Respondent 16 & Baby care accessories & 3 & Female \\
\hline Respondent 17 & Plumber & 5 & Male \\
\hline
\end{tabular}

The interviews were conducted in March and April 2017. Each interview was audiorecorded, transcribed into a Microsoft Word document, and subjected to thematic analysis.

Permission to conduct the study was obtained from the Western Cape Government's Department of Economic Development and Tourism. Research Ethical Clearance approval was obtained from the University of Cape Town, since the research was conducted in partial fulfilment of the lead author's Master of Commerce in Information Systems degree. 


\section{Findings}

\section{Commodity 1: ICTs for general business activities}

In respect of ICTs for general business activities as a commodity, it was found that most of the 17 microenterprises used only generic and affordable ICTs for general business activities, with some notable exceptions. The exceptions were as follows: the microenterprise providing mobile phone accessories owned a point-of-sale system in addition to a laptop and mobile device; the mechanic used specialised software on his laptop to diagnose car repair issues for newer vehicle models; and the locksmith used expensive software to cut specific keys for clients.

Table 3 summarises the ICTs owned and used for general business activities by the 17 microenterprises whose owners were interviewed in this study.

Table 3: ICTs owned and used by the 17 microenterprises

\begin{tabular}{|c|c|c|}
\hline ICT owned and used & Uses & $\begin{array}{c}\text { No. of } \\
\text { microenterprises }\end{array}$ \\
\hline Mobile phone & $\begin{array}{ll}\text { - } & \text { communicating with friends } \\
\text { - } & \text { communicating with suppliers } \\
\text { - } & \text { searching for information } \\
\text { - } & \text { electronic fund transfers } \\
\text { - } & \text { online marketing } \\
\text { - } & \text { mobility }\end{array}$ & 17 \\
\hline Laptop & $\begin{array}{l}\text { - } \quad \text { communicating with clients } \\
\text { - } \quad \text { invoicing } \\
\text { - } \quad \text { drafching for information } \\
\text { - } \quad \text { diagnosing car issues } \\
\text { - } \quad \text { online marketing } \\
\text { - } \quad \text { web design }\end{array}$ & 14 \\
\hline PC & $\begin{array}{ll}\text { - } & \text { communicating with clients } \\
\text { - } & \text { communicating with suppliers } \\
\text { - } & \text { invoicing } \\
\text { - } & \text { searching for information } \\
\text { - } & \text { web design }\end{array}$ & 4 \\
\hline Printer & $\begin{array}{l}\text { - } \quad \text { printing legal documents } \\
\text { - } \quad \text { printing pamphlets }\end{array}$ & 2 \\
\hline Point-of-sale devices & - $\quad$ selling airtime vouchers & 1 \\
\hline
\end{tabular}




\section{Capabilities}

The potential capabilities cited by the 17 interviewees included access to information, communication, marketing exposure, cost-savings, efficiency and productivity. In respect of communication, respondent 15 spoke of the potential capabilities in these terms:

Now you can just email all the documents, but before that wasn't available. You had to go and sit with them [i.e. clients] and fill it in. So, everything is done via the email now.

On the subject of information access, respondent 2 said:

It makes accessing information much quicker.

The owner of the mobile phone accessories microenterprise was of the view that a potential opportunity for use of the ICT commodity was that it made access to information much quicker.

The beautician (respondent 11) said that, in terms of marketing exposure, it helped her to improve the brand awareness of her business.

With social media it's easier to get the word out there.

One of the e-commerce microenterprise owners (respondent 4) cited cost savings as a capability offered by ICTs:

I think one benefits, that you can save a lot of cost by using technology. So, it drives down overheads [for my business].

\section{Conversion factors}

It was found that infrastructure (ICT facilities) and resources (ICT resources) influenced how the microenterprises generated a capability set to use the ICT commodity for general business activities. All 17 microenterprises had access to internal ICT facilities in their businesses, which enabled them to use the ICT commodity. Therefore, they did not experience the challenge of having to use shared ICT facilities, such as telecentres and internet cafés, which could affect their general business activities. Furthermore, the 17 microenterprises also had access to ICT resources such as mobile phones, laptops and PCs, which enabled them to use the ICT commodities.

No barriers were identified in respect of the ICT literacy and skills needed to use the ICT commodity for general business activities. The microenterprise owners had 
either received computer training from a technical college or were self-taught. All could competently use the ICTs they needed. In the words of the locksmith (respondent 10):

Any computer training that I got was from learning and educating myself.

Instances were identified where socio-economic factors impacted how a microenterprise generated a capability set to use the ICT commodity. For example, the plumber said he used a mobile phone to communicate with clients, to purchase materials and to search for information, with the mobile phone having to serve as his main ICT tool because he could not afford to buy a laptop.

\section{Functionings}

The study determined that the microenterprises found that an ICT, i.e., the internet, enabled them to access information such as product and supplier information more quickly. According to respondent 7:

It has helped me to find [information] that I'm looking for [on the Internet] quicker.

Furthermore, some microenterprises were found to be using their mobile phones, and mobile applications such as WhatsApp, to improve communication with their clients. The beautician (respondent 11) used ICT, in the form of social media platforms (e.g. Facebook and Instagram) to promote her brand and to improve the marketing of her products.

It definitely has [allowed me to acquire more clients]. So, I post something on social media, and one girl is gonna share it on her [social media] page, and 10 of her friends are gonna see it, and out of that 10, maybe five [are] gonna share it, and so forth. That is how I've built up my clientele, and my name is quite well known because of that.

The mechanic stated that using ICTs enabled him to operate his businesses efficiently and to improve his productivity.

\section{Commodity 2: Online government business support information}

\section{Capabilities}

The interviewed microenterprise owners identified a number of capabilities that could potentially be harnessed via access to, and use of, online government business support information, including: improved competitiveness; accelerated business growth; improved business management skills, especially marketing skills; additional products and services; acquisition of more clientele; access to new markets; and increased staff employment. 
In the words of the locksmith (respondent 10):

If we had some form of support in that aspect, then I think that the fiveyear plan that we have would probably turn into two years. It will accelerate growth big time by far.

The car accessories microenterprise owner (respondent 7) suggested that use of online government business support information commodity could create an opportunity for him to grow his business.

If I could access it, I could perhaps grow my existing business. I could open [a store] in a good location where I could sell on a bigger scale. At the moment, I'm selling on a small scale from home.

The mechanic (respondent 9) said he believed that using government business support information, particularly funding information, could improve the competitiveness of his business, and allow him to employ additional staff.

You'll obviously employ more people as well. You'll look at increasing the employment level.

The clothing manufacturer stated that accessing online government business support information could help him to market his products.

\section{Conversion factors}

It was found that none of the microenterprises could generate functionings from the government websites because of the challenges they experienced in trying to use the sites' business support information. The clothing manufacturer (respondent 3) had tried to find government support information relating to funding (grants and/or loans), but had been unsuccessful. The plumber (respondent 17) had tried unsuccessfully to find support information on business management skills training for his business.

I tried to access support information for business training because remember we have to run the business in a professional way, so the one thing that we are lacking is how to operate this business efficiently and effectively.

The microenterprises had experienced several challenges in seeking to use support information on government websites to improve the competitiveness of their businesses. The car accessories owner (respondent 16) said that it was difficult, on the government websites, "to find information that is current and not missing anything". The caterer (respondent 13) complained that the sites tended to list outdated contact details. 
Another challenge cited was that the support information was not structured to meet the needs of businesses at different maturity levels. According to expert respondent 1 :

[The Western Cape] Government does not offer that [diverse information] because they don't know what is needed. They just use their own idea. If they knew, then they [would] put that [on their] website.

It was stated that the government websites in question needed to be more mobilefriendly, thus improving the accessibility of the support information. According to expert respondent 1 :

As a businessman, I want a website that can scale nicely for mobile use.

The microenterprises also found that navigation of the online government business support information was difficult, which limited their use of the information:

It's not easy to navigate. (respondent 3)

You don't know where to start [using the website once you get there]. It's organised chaos. (respondent 1 )

Additionally, it was found that lack of content in the isiXhosa language was a challenge that prevented some microenterprises from using the support information.

The one thing that I found out is that it's very difficult for an isiXhosaspeaking person because they [do] not have that website in isiXhosa translation. It was only in English and Afrikaans. If it's not sort of like trilingual, because English, Afrikaans and isiXhosa are the predominant languages in the Western Cape, then how [do] they expect people [to access the support information]? (respondent 15)

\section{Functionings}

The capabilities discussed above were those identified by the microenterprise owners as potentially resulting if they could make use of online government business support information. Therefore, their discussions of functionings were only in respect of potential, not actual, functionings. 
The plumber (respondent 17) mentioned that he could use funding gained via support information to purchase additional vehicles and equipment, thereby increasing the operational capacity of, and growing, his business.

It [would] help me to buy more vehicles because I want to buy more vehicles. Normally [in] the business of plumbing, the basic thing that you need is a vehicle, and buying equipment.

Another microenterprise owner spoke of potential functionings that could arise from business management skills training, especially marketing training, if he could find such training via online government support information.

If I received training on marketing, I could market and sell my products better. (respondent 2)

The locksmith (respondent 10) also cited potential functionings that could emerge if online government information could connect him to business skills development opportunities-including, for example, branching out into closed-circuit television accessories:

It would create [new] services for our business.

The mobile phone accessories microenterprise owner (respondent 2) said that if he could grow his business through using online government support information, he would expand his operations into new markets.

[Accessing support information] would allow me to open another shop that could also create more opportunities for employment.

The bookkeeper said that if he could make use of online government support information on how to provide internships to unemployed graduates, he could train and mentor graduates, thereby indirectly contributing towards mitigating the high unemployment rate in South Africa.

\section{Freedom, agency and well-being}

Elements of potential freedom, agency and well-being cited by the interviewed microenterprise owners as being potentially linked to online government business support information included: women's empowerment, an improved standard of living, increased self-confidence and increased motivation. 
The locksmith, car accessories microenterprise owner and clothing retailer all stated that they believed use of online support information on matters of funding and skills development could, by improving the competitiveness of their businesses, enable them to more freely pursue their personal objectives and interests, such as accessing higher education, building a home, and achieving an improved standard of living.

Personally, it would give me the opportunity to do the things that I love doing ... which is to study, to learn more, and to grow [personally]. [respondent 10]

It would speed up my personal goals. For example, I would like to build my own house. [respondent 7]

It [would] improve my standard of living. [respondent 6]

The mobile phone accessories enterprise owner (respondent 2) believed that if he could use online government support information to make his business more stable, it would enable him to achieve his personal objective, which was to devote more energy to his home life.

It would give me more time to spend with my family.

The caterer believed that if she could access funding, it would give her the freedom to achieve her personal objective, which was to empower female homemakers by training them to cook and cater at small-scale events.

\section{Discussion}

\section{Microenterprises' use of ICTs for general business activities}

The study found that microenterprises mostly used mobile phones (all 17 enterprises) and laptops (14 enterprises) for general business activities. This aligns with the findings of Donner (2006) and Esselaar et al. (2007) that microenterprise owners mostly use mobile phones for their business activities. Among the benefits of mobile phones for microenterprises are immediate access to, and better use of, information, and rapid communication (i.e., rapid information flow) (Julsrud \& Rolan, 2014).

The study found that some of the microenterprises favoured the use of mobile phones, as opposed to laptops, for information access, because of the challenge of affordability, i.e., not having the necessary funds to purchase or lease a laptop. For instance, the plumber said he used his mobile phone for most of the functions of his business-including communicating with clients, purchasing materials and searching for information-because he could not afford a laptop. 
The microenterprises were also found to be attempting to access support information relating to business skills development, products and services development, and funding. Literature suggests that individuals seek information to satisfy a knowledge gap or a desired goal (Malanga \& Jorosi, 2018). This was evident in the information needs that were identified by the enterprises, e.g., information on marketing, products and services, and grant and loan information.

There was an expectation that some microenterprises would access business support information through shared ICT facilities, such as telecentres and internet cafés. This expectation was based on existing research showing that ineffective ICT infrastructure and limited ICT resources are among the many ICT challenges that microenterprises experience in developing countries (Chigona, Lekwane, Westcott \& Chigona, 2011), and that shared ICT facilities would therefore be attractive to the enterprises. However, this was found not to be the case with the respondents in this study.

\section{Microenterprises'experiences with online government support information}

It was found that the microenterprises surveyed experienced several challenges with using online government support information. Among other things, the microenterprises generally found that the online government support information tended to be outdated, incomplete and unreliable. This finding aligns with statements in Parliament, to the National Council of Provinces (NCOP) Economic and Business Development Committee, to the effect that microenterprises experience challenges in finding and accessing reliable information (PMG, 2012).

It was found that the microenterprises also regarded online government support information as often irrelevant, i.e., because the information was not structured to meet the needs of businesses at different maturity levels, from start-ups to established businesses. The majority of participants in this study were established businesses, and therefore required support information linked to growing their businesses and becoming more competitive. However, the respondents found that most of the online government support information was aimed at start-up businesses. The digital government expert interviewee who consulted to the Western Cape Government said that the government did not offer diverse online support information because it was not sufficiently aware of what businesses at different maturity levels needed (expert respondent 2).

Some enterprise owners said they found certain online business support information too complex and sometimes even incomprehensible. This challenge was found to have prevented the clothing manufacturer from accessing support information relating to grants and loans. This finding corresponds with Makoza's (2011) finding that many microenterprises struggle to evaluate support information and to apply the information in their business activities. It was also found that the microenterprises 
were critical of the navigation modalities of government websites. This finding aligns with Lotriet's (2005) finding that ineffective website design can lead to inaccessibility of information. Surveyed enterprise owners also stated that government websites were not designed to be mobile-friendly, thus creating an additional usage barrier.

Another complaint voiced by some of the surveyed enterprise owners was that a barrier was created by the absence of government website content in the isiXhosa language, which was the home language of many of the microenterprise owners. This finding corresponds with the findings from a study by Agangiba and Kabanda (2016), who found that aspects of culture, such as language, can be substantial obstacles to the use of digital government services.

Also identified by the microenterprise owners surveyed were the challenges presented by cumbersome bureaucratic procedures linked to government online business support, e.g., applications for funding. One of the e-commerce microenterprise owners (respondent 15) said he had to complete a 20-page questionnaire just to see if he could qualify for funding. This finding aligns with findings from other research showing that some of the biggest hindrances to the growth of entrepreneurs in South Africa are the many regulatory obstacles (Mitrovic \& Bytheway, 2009). The challenges that South African small enterprises experience when seeking to comply with regulations have also been voiced in Parliament, in the aforementioned hearing of the NCOP Economic and Business Development Committee (PMG, 2012).

\section{Conclusions}

The study sought to explore the challenges that microenterprises in South Africa's Western Cape Province experience in using ICTs and in using support information on government websites. Guided by the capability approach framework, we treated ICTs and online government business support information as two separate commodities.

In respect of the first commodity-ICTs - it was found that the microenterprise owners had an appreciation for ICTs, and were able to gain several benefits from using them, including improved access to information, improved communication, improved marketing, reduced costs, improved efficiency and improved productivity. It was also found that the microenterprise owners did not experience any particular ICT access or usage challenges.

In respect of the second commodity - government online business support informationit was found that the microenterprises experienced challenges when they attempted to access and use the information. The difficulties encountered were found to be a result of deficiencies in content, structure, design, navigation, mobile-friendliness, language provision and bureaucratic requirements. These challenges were found to limit the benefits that the microenterprises could derive from the support information. It is 
thus evident that for the G2B information services to be of value to Western Cape microenterprises, numerous deficiencies must be addressed.

The support information must be up-to-date, complete and relevant for established businesses. There is also a need for the structure of the support information to be simplified, i.e., the information must be made clearer and easier to comprehend. The information targeting Western Cape businesses should be available in at least three languages: English, Afrikaans and isiXhosa. We also recommend the development of a national, centralised and inclusive G2B portal that links to all South African online government business support information at the national, provincial and municipal levels. This would help the South African Government to more fully pursue digital transformation of its support services to microenterprises, and, in turn, to stimulate enhanced economic growth.

\section{References}

Abor, J., \& Quartey, P. (2010). Issues in SME development in Ghana and South Africa. International Research Journal of Finance and Economics, 39, 218-228.

Agangiba,M.,\& Kabanda,S. (2016).E-government accessibility research trends in developing countries. In Proceedings of the Mediterranean Conference on Information Systems (pp. $1-18)$.

Alampay, E. A. (2006). Beyond access to ICTs: Measuring capabilities in the information society. International Journal of Education and Development using Information and Communication Technology, 2(3), 4-22.

Alexander, P. M., \& Phahlamohlaka, L.J. (2006). Amartya Sen's Capability Approach applied to Information Systems research. South African Computer Journal, 37, 1-11.

Bwalya, K. J., \& Healy, M. (2010). Harnessing e-government adoption in the SADC region: A conceptual underpinning. Electronic Journal of e-Government, 8(1), 23-32.

Bwalya, K. J., Du Plessis, T., \& Rensleigh, C. (2013). Multi-dimensional factors impacting on e-government adoption in Botswana, Mozambique, and Malawi. In S. K. Sharma (Ed.), Adoption of virtual technologies for business, educational, and governmental advancements. Hershey, PA: IGI Global. https://doi.org/10.4018/978-1-4666-2053-7.ch005

Chacko, J. G., \& Harris, G. (2006). Information and communication technology and small, medium, and micro enterprises in Asia-Pacific - size does matter. Information Technology for Development, 12(2), 75-177. https://doi.org/10.1002/itdj.20034

Charman, A. (2016). The South African township economy and informal micro-enterprises: What are the prospects for youth employment and entrepreneurship? Washington, DC: Development Policy Research Unit, World Bank.

Chigona, W., Lekwane, O., Westcott, K., \& Chigona, A. (2011). Uses, benefits and challenges of public access points in the face of growth of mobile technology. The Electronic Journal of Information Systems in Developing Countries, 49(5), 1-14. https://doi.org/10.1002/j.1681-4835.2011.tb00349.x

City of Cape Town. (n.d.). [Website]. Retrieved from https://www.capetown.gov.za/ 
Department of Small Business Development. (2019). Revised Schedule 1 of the National Definition of Small Enterprise in South Africa. Pretoria: Government of South Africa.

Department of Trade and Industry (DTI).(n.d.).Small medium micro enterprise development. Retrieved from http://www.dti.gov.za/sme development/sme development.jsp

Donner, J. (2006). The use of mobile phones by microentrepreneurs in Kigali, Rwanda: Changes to social and business networks. Information Technologies and International Development, 3(2), 3-19. https://doi.org/10.1162/itid.2007.3.2.3

Duncombe, R., \& Heeks, R. (2005). Information and communication technologies (ICTs), poverty reduction and micro, small and medium-scale enterprises (MSMEs). Manchester: Institute for Development Policy and Management (IDPM), University of Manchester.

Esselaar, S., Stork, C., Ndawalana, A., \& Deen-Swarray, M. (2007). ICT usage and its impact on profitability of SMEs in 13 African countries. Information Technologies and International Development, 4(1), 87-100. https://doi.org/10.1162/itid.2007.4.1.87

Gigler, B.-S. (2004). Including the excluded - Can ICTs empower poor communities? Towards an alternative evaluation framework based on the capability approach. Paper presented at the 4th International Conference on the Capability Approach, 5-7 September, University of Pavia, Italy.

Good, T., \& Qureshi, S. (2009). Investigating the effects of micro-enterprise access and use of ICTs through a capability lens: Implications for global development. In Proceedings of the 2nd Annual SIG GlobDev Workshop, Phoenix, AZ, December 14.

Grönlund, Å. (2011). Connecting egovernment to real government: The failure of the UN eParticipation Index. In M. Janssen, H. J. Scholl, M. A. Wimmer, \& Y.-H. Tan (Eds.), Electronic Government: 10th IFIP WG 8.5 International Conference, EGOV 2011, Delft, The Netherlands, August 28 - September 2, 2011: Proceedings (pp. 26-37). Berlin: Springer. https://doi.org/10.1007/978-3-642-22878-0 3

Grunfeld, H., Hak, S., \& Pin, T. (2011). Understanding benefits realisation of iREACH from a capability approach perspective. Ethics and Information Technology, 13(2), 151-172. https://doi.org/10.1007/s10676-011-9268-4

International Financial Corporation (IFC), \& World Bank (2018). The unseen sector: A report on the MSME opportunity in South Africa. Washington, DC.

Jantjies, S. O. (2010). An evaluation of e-government within the Provincial Government Western Cape (PGWC). Master's dissertation, University of Stellenbosch, South Africa.

Julsrud, T. E., \& Rolan, M. D. G. Z. (2014). Mobile phones and business networks among Malaysian micro and small enterprises: A comparative network approach. AsiaPacific Social Science Review, 14(1), 21-42.

Kaisara, G., \& Pather, S. (2011). The e-government evaluation challenge: A South African Batho Pele-aligned service quality approach. Government Information Quarterly, 28(2), 211-221. https://doi.org/10.1016/j.giq.2010.07.008

Kamal, M., \& Qureshi, S. (2009). Sustaining the growth of micro-enterprises that adopt information and communication technologies. In Proceedings of the Annual Workshop of the AIS Special Interest Group for ICT in Global Development, Phoenix, AZ.

Lotriet, H. (2005). Accessibility of South African Web sites to visually disabled users. South African Journal of Information Management, 7(2), 1-9. https://doi.org/10.4102/sajim.v7i2.263 
Malanga, D. F., \& Jorosi, B. N. (2018). Information literacy skills among the undergraduate students at the University of Livingstonia,Malawi. International Journal of Library and Information Services (IJLIS), 7(2), 43-56. https://doi.org/10.4018/ijlis.2018070104

Makoza, F. (2011). The impact of ICT use on livelihoods of microenterprises: Case of South Africa. Master's dissertation, University of Cape Town.

Makoza, F., \& Chigona, W. (2012). The livelihood outcomes of ICT use in microenterprises: The case for South Africa. The Electronic Journal on Information Systems in Developing Countries, 53(1), 1-16. https://doi.org/10.1002/j.1681-4835.2012.tb00374.x

Makoza, F., \& Chigona, W. (2014). Accessibility of e-government websites: Case of Malawi. In Proceedings of the 15th Annual Conference on World Wide Web Applications, Cape Town (pp. 10-13).

Malik, B. H., Shuqin, C., Mastoi, A. G., Gul, N., \& Gul, H. (2016). Evaluating citizen e-satisfaction from e-government services: A case of Pakistan. European Scientific Journal, 12(5), 346-370. https://doi.org/10.19044/esj.2016.v12n5p346

Matavire, R., Chigona, W., Roode, D., Sewchurran, E., Davids, Z., Mukudu, A., \& BoamahAbu, C. (2010). Challenges of egovernment project implementation in a South African context. The Electronic Journal Information Systems Evaluation, 13(2), 153164.

Mawela, T., Ochara, N. M., \& Twinomurinzi, H. (2016). E-government implementation: Lessons from South African municipalities. In SAICSIT 16: Proceedings of the Annual Conference of the South African Institute of Computer Scientists and Information Technologists, Johannesburg, September 26-28. https://doi.org/10.1145/2987491.2987499

Moyi, E. D. (2003). Networks, information and small enterprises: New technologies and the ambiguity of empowerment. Information Technology for Development, 10(4), 221232. https://doi.org/10.1002/itdj.1590100402

Mitrovic, Z., \& Bytheway, A. (2009). Awareness of e-government related small business development services in Cape Town. The Electronic Journal of Information Systems in Developing Countries, 39(4), 1-14. https://doi.org/10.1002/j.1681-4835.2009.tb00278.x

Mutula, S. M. (2013). E-government divide: Implications for sub-Saharan Africa. In D. Ocholla, J. Britz, R. Capurro, \& C. Bester (Eds.), Information ethics for Africa: Crosscutting themes (pp. 59-69). Pretoria: African Centre of Excellence for Information Ethics, University of Pretoria.

Noruwana, L., Chigona, W., \& Malanga, D. F. (2018). How information and communication technologies empower disadvantaged communities in Cape Town, South Africa. In SAICSIT'18: Proceedings of the Annual Conference of the South African Institute of Computer Scientists and Information Technologies, Port Elizabeth, South Africa (pp. 171-178). https://doi.org/10.1145/3278681.3278702

Nussbaum, M. (2009). Capabilities as fundamental entitlements: Sen and social justice. In K. Schneider, \& H.-U. Otto (Eds.), From employability towards capability (pp. 15-43). Luxembourg: Inter-Actions.

Nyemba-Mudenda, M. (2014). A pathway through which mhealth outcomes are produced for maternal healthcare consumers in a developing country context. $\mathrm{PhD}$ thesis, University of Cape Town. 
Nyemba-Mudenda, M., \& Chigona, W. (2017). mHealth outcomes for pregnant women in Malawi: A capability perspective. Information Technology for Development, 24(2), 245-278. https://doi.org/10.1080/02681102.2017.1397594

Parliamentary Monitoring Group (PMG). (2012). Small medium \& micro enterprises [Summary of Committee meeting]. Economic and Business Development Committee, National Council of Provinces (NCOP). Retrieved from https://pmg. org.za/committee-meeting/15288/

Praditya, D., \& Janssen, M. (2015). Benefits and challenges in information sharing between the public and private sectors. In Proceedings of the 15th European Conference on e-Government 2015: ECEG 2015 (pp. 246-253).

Research ICT Africa (RIA), \& University of Cape Town (UCT). (2018). Western Cape digital readiness assessment 2015. For the Western Cape Department of Economic Development and Tourism. Retrieved from https://www.westerncape.gov.za/assets/ departments/economic-development-tourism/digital readiness full report.pdf

Robeyns,I. (2003). The capability approach: An interdisciplinary introduction. Paper presented to Training Course preceding $3^{\text {rd }}$ International Conference on the Capability Approach, Pavia, Italy, 6 September. Retrieved from https://www.semanticscholar. org/paper/The-Capability-Approach\%3A-An-Interdisciplinary-Robeyns/49fbe60 b5aa9152d3789e43b8991bc6034f24f49

Robeyns, I. (2005). The capability approach: A theoretical survey. Journal of Human Development, 6(1), 93-117. https://doi.org/10.1080/146498805200034266

Robeyns, I. (2006). The capability approach in practice. Journal of Political Philosophy, 14(3), 351-376. https://doi.org/10.1111/j.1467-9760.2006.00263.x

Rogerson, C. (2008). Tracking SMME development in South Africa: Issues of finance, training and the regulatory environment. Urban Forum, 19(1), 61-81. https://doi. org/10.1007/s12132-008-9025-x

Rubaii-Barrett, N., \& Wise, L. R. (2008). Disability access and e-government: An empirical analysis of state practices. Journal of Disability Policy Studies, 19(1), 52-64. https://doi.org/10.1177/1044207307311533

Sen, A. (1993). Capability and well-being. In M. Nussbaum, \& A. Sen (Eds.). The quality of life. Oxford: Blackwell. https://doi.org/10.1093/0198287976.003.0003

Sekaran, U., \& Bougie, R. (2011). Research methods for business: A skill-building approach. New York: John Wiley \& Sons.

Shambour, Q. Y. (2012). Hybrid recommender systems for personalized government-to-business e-services. PhD thesis, University of Technology, Sydney.

Statistics South Africa (Stats SA). (n.d.). Tourism: Employment, economy, and foreign income. Retrieved from http://www.statssa.gov.za/?p=6166

Venter, S., \& Lotriet, H. (2005). Accessibility of South African Web sites to visually disabled users. South African Journal of Information Management, 7(2), 1-15. https://doi.org/10.4102/sajim.v7i2.263

Walton, P., Kop, T., Spriggs, D., \& Fitzgerald, B. (2013). Digital inclusion: Empowering all Australians. Australian Journal of Telecommunications and the Digital Economy, 1(1), 1-17. https://doi.org/10.7790/ajtde.v1n1.9

Western Cape Government (2012). eGovernment strategy, 2012-2019. Retrieved from https://www.westerncape.gov.za/text/2012/10/wcg-draft-e-government-strategyfor-public-comment-october-2012.pdf 
Western Cape Government. (n.d.). Western Cape Government: Overview. Retrieved from https://www.westerncape.gov.za/your gov/70

Woodward, D., Rolfe, R., Ligthelm, A., \& Guimaraes, P. (2011). The viability of informal microenterprise in South Africa. Journal of Developmental Entrepreneurship, 16(1), 65-86. https://doi.org/10.1142/S1084946711001719

Yildiz, M. (2007). E-government research: Reviewing the literature, limitations, and ways forward. Government Information Quarterly, 24(3), 646-665. https://doi.org/10.1016/j.giq.2007.01.002

Zaidi,S.F.H., \& Qteishat,M.K.(2012).Assessing e-government service delivery (government to citizen). International Journal of eBusiness and eGovernment Studies, 4(1), 45-54.

Zheng, Y., \& Walsham, G. (2008). Inequality of what? Social exclusion in the e-society as capability deprivation. Information Technology and People, 21(3), 222-243.

https://doi.org/10.1108/09593840810896000

\section{Appendix: Interview protocol}

\section{Opening}

1. What are your business goals, which you aim to achieve?

\section{List of capabilities (potential functionings)}

2. What are the potential opportunities of using ICTs for your business?

3. What are the potential opportunities of accessing government online support information for your business?

\section{Conversion factors for generating a capability set}

4. How do you access ICTs for your business (i.e. internal or shared ICT facilities)?

5. Which ICT devices do you use for your business?

6. Have you received computer training on to how to use the ICT devices?

7. What type of government websites do you use to search for online government support information?

8. What type of online government support information have you accessed or attempted to access?

\section{Conversion factors affecting outcome}

9. How competently can you use the ICT devices for your business?

10. What challenges do you experience in accessing online government support information for your business?

\section{Outcome of ICTs for general business (achieved functionings)}

11. How has technology enabled you to achieve your business goals?

Outcome of online government business support information (potential achieved functionings)

12. How would access and use of support information enable you to achieve your business goals?

\section{Personal agency}

13. How would access and use of ICTs for business enable you to achieve your goals?

14. How would access and use of support information enable you to achieve your personal goals? 